\title{
時季および花（花蕾）の処理が単為結果性トマト品種 ‘ルネッサンス’の着果および果実特性に及ぼす影響
}

\author{
大川浩司 $*$ ・菅原眞治・矢部和則 \\ 愛知県農業総合試験場 480-1193 愛知県愛知郡長久手町
}

\begin{abstract}
Effects of Season and Flower (Bud) Treatment on the Fruit Setting, Fruit Thickening Characteristics of the Parthenocarpic Tomato Variety 'Renaissance'
\end{abstract}

\author{
Hiroshi Ohkawa*, Shinji Sugahara and Kazunori Yabe \\ Aichi-ken Agricultural Research Center, Nagakute-cho, Aichi 480-1193
}

\begin{abstract}
Summary
Fruit setting, fruit thickening characteristics of the parthenocarpic tomato variety 'Renaissance' in spring, early summer, autumn and winter which are the blooming seasons of the main cropping system in Aichi prefecture were examined. Fruit setting percentage of 'Renaissance' in spring, early summer, autumn, winter was very high. There were no undergrown fruit and the parthenocarpic characteristics of 'Renaissance' were very strong in these seasons. In 'Renaissance', fruit weight and days required till harvest were not influenced by production of seeds or treatment with 4-chlorophenoxy acetic acid (15 mg/L). These results suggested that productivity of 'Renaissance' was higher than that of the non-parthenocarpic tomato variety.
\end{abstract}

Key Words : fruit setting percentage, productivity, undergrown fruit

キーワード : 発育不良果, 生産性, 着果率

\begin{abstract}
緒言
トマトの施設栽培では, 着果を安定させるためにセイヨ ウオオマルハナバチ（Bombus terrestris）（以下マルハナバ チ）による受粉（池田・忠内, 1992; 小出・林, 1993）や合 成ホルモン剂の処理（Ho・Hewitt, 1986）が行われている. しかし, これらの処理はいずれもコストや労力を増大させ る. 現在, 実用品種の大部分が強い単為結果性を持ってい るキュウリ（斎藤，1995）のように施設栽培トマトも単為 結果性を有すれば，振動受粉や合成ホルモン剂処理が不 要となり, 生産性の高い栽培が可能になる。菅原らは, 口 シアの品種 ‘Severianin’ が持つ単為結果性遺伝子 pat-2 (Philouze・Maisonneuve, 1978a, 1978b) を我が国のトマトの 実用品種に導入することを試み, 1994 年に初めての実用的 な単為結果性品種でファースト型の ‘ラークナファースト’ （菅原ら，1995）を，2000 年に完熟収穫型の ‘ルネッサンス’ （菅原ら，2002）を育成した. これらの単為結果性品種を安 定して生産するには，施設栽培に打ける着果および果実特
\end{abstract}

2005 年 6 月 13 日 受付. 2005 年 10 月 28 日 受理.

本報告の一部は，園芸学会平成 15 年度秋季大会で発表した。

* Corresponding author. E-mail: hiroshi_ookawa@pref.aichi.lg.jp

現在 : 愛知県庁農業経営課 460-8501 名古屋市中区三の丸
性を詳細に明らかにして打く必要があるが，池田ら（2003） 以外にその報告はない。一方, 愛知県における施設栽培卜 マトの主要作型は, 促成短期, 促成長期, 抑制, 半促成抒 よび夏秋栽培であり, 一年を通じ平坦地域から中山間地域 においてトマトの栽培が行われている.

そこで，本研究では愛知県の主要作型の開花時期に当た る春季, 初夏季, 秋季拈よび冬季での単為結果性品種 ‘ ネッサンス’の着果扣よび果実特性を, 非単為結果性品種 “桃太郎ヨーク’を対照に比較検討した。

\section{材料および方法}

供試材料は, 単為結果性を示す品種として‘ルネッサン ス’を，単為結果性を示さない一般的な品種として“桃太 郎ヨーク’ (対照品種) を用いた. 試験は, 愛知県の主要作 型に扣ける開花時期を想定し，春，初夏，秋および冬とい ら環境の大きく異なる時季に，いずれもガラス温室内で 行った. 単為結果性の発現, 合成ホルモン剂, 受粉・受精 による着果を比較するため, 花 (花蕾) の処理として除雄, 除雄 +4-chlorophenoxy acetic acid (以下 4CPA), 振動受粉 に, 単為結果性品種の実際の栽培を想定して花（花蕾）の 処理を全く行わない放任を加え, 計 4 種類の処理を行った. 除雄は開花 1〜3 日前に雄ずいを除去し, 除雄 $+4 \mathrm{CPA}$ は除 雄した花を開花当日に 4CPA 液（濃度 $15 \mathrm{mg} / \mathrm{L}$ ）に浸漬し 
た. また，振動受粉は開花当日に花を振動させた，両品種 と夕, 時季 (4) × 花 (花蕾) の処理 (4) の計 16 処理区を設 けた. 春季, 秋季および冬季では 4 段摘心栽培, 初夏季で は 3 段摘心栽培とし，春季は 1 月 20 日播種，3 月 12 日定 植株の第 $2 \sim 3$ 花房を, 初夏季は 5 月 1 日播種, 5 月 28 日 定植株の第 $1 \sim 2$ 花房を, 秋季は 8 月 7 日播種, 9 月 12 日 定植株の第 3 花房を, 冬季は 11 月 1 日播種, 12 月 10 日定 植株の第 $2 \sim 3$ 花房を調査に供した. 花房当たりの処理花 数は 3 花で, その他の花はすべて除去し, 調査対象果数は 1 処理区当たり春季拈よび冬季は 24 果, 初夏季は 18 果, 秋 季は 12 果とした. 換気温度はいずれの時季も $28^{\circ} \mathrm{C}$ とし, 最低は $10^{\circ} \mathrm{C}$ を維持するように加温した. また, 両品種とも 複合液肥（14-8-16）を用いた養液土耕栽培を行った。調査 項目は, 正常果数, 発育不良果（着色が通常の果に比べ遅 れ, つやがなく, 肥大が明らかに悪い果実）数, 有種子果 数, 開花から収穫までの日数, 一果重, 種子数および空洞 程度とした．空洞程度は果実を赤道面で横断して，0（無） $\sim 4$ (甚) の 5 段階評価を行い， $\Sigma$ (空洞指数 $\times$ 果実数）／ 調査果実数を算出した。な括, 発育不良果执よび尻腐れ果 は果実特性の調査対象から除外した。

\section{結＼cjkstart果}

各時季における両品種の開花時期は，春季が 4 月上旬〜 中旬, 初夏季が 6 月中旬〜下旬, 秋季が 10 月上旬〜中旬, 冬季が 1 月中旬〜 2 月上旬であった.

\section{着果数（正常果数, 発育不良果数)}

‘ルネッサンス’の着果率は, 初夏季の除雄 $+4 \mathrm{CPA}$ 区が 94\%であった以外，時季拈よび花（花蕾）の処理に関係な くいずれも 100\%で，かつ，そのすべてが正常果であり，発 育不良果は全く発生しなかった.

“桃太郎ヨーク’ の着果状況は以下のと抢りであった．春
季の場合，着果率は除雄 $+4 \mathrm{CPA}$ 区が $100 \%$ ，振動受粉区が 96\%で，そのほぼ全てが正常果であったが，放任区は $83 \%$ で，その約半数が発育不良果であり，除雄区は $58 \%$ で，そ の全てが発育不良果であった。初夏季の場合，着果率は除 雄 +4CPA 区が $89 \%$ ，振動受粉区が $100 \%$ ，放任区が $56 \%$ で，その全てが正常果であったが，除雄区では全く着果し なかった．秋季の場合，着果率は除雄 $+4 \mathrm{CPA}$ 区抏よび放任 区が 92\%，振動受粉区が 100\%で，その全てが正常果で あったが，除雄区は77\%で，その全てが発育不良果であっ た. 冬季の場合，着果率はいずれの処理でも 96\%以上で あったが，除雄 +4CPA 区でその全てが，振動受粉区で約 3 割が正常果であった以外は，いずれも発育不良果であった (第 1 図).

\section{有種子果}

両品種とも，いずれの時季でも除雄区および除雄 +4CPA 区では有種子果は全く発生しなかった. ‘ルネッサンス’の 有種子果率は，春季，初夏季拈よび秋季では振動受粉区が いずれも 92\%であったが，放任区は振動受粉区に比べて大 幅に低く, 冬季では振動受粉区が $9 \%$, 放任区が $0 \%$ と両区 とも極めて低率であった。“桃太郎ョーク’ の有種子果率 は，初夏季拈よび秋季では振動受粉区未よび放任区とも 100\%であったが，春季では振動受粉区が 96\%，放任区が $48 \%$ ，冬季では振動受粉区が $46 \%$ ，放任区が $0 \%$ であった (第 2 図).

\section{果実特性}

開花から収穫までの日数は，いずれの時季とも‘ルネッ サンス’では処理区間に差はなかったが，“桃太郎ョーク’ では除雄 +4CPA 区が他の処理に比べて短い傾向で, 特にそ れは初夏季および秋季で顕著であった。

一果重は, ‘ルネッサンス’ではいずれの時季でも処理区 間に差はなかったが，“桃太郎ヨーク’では春季，初夏季抒

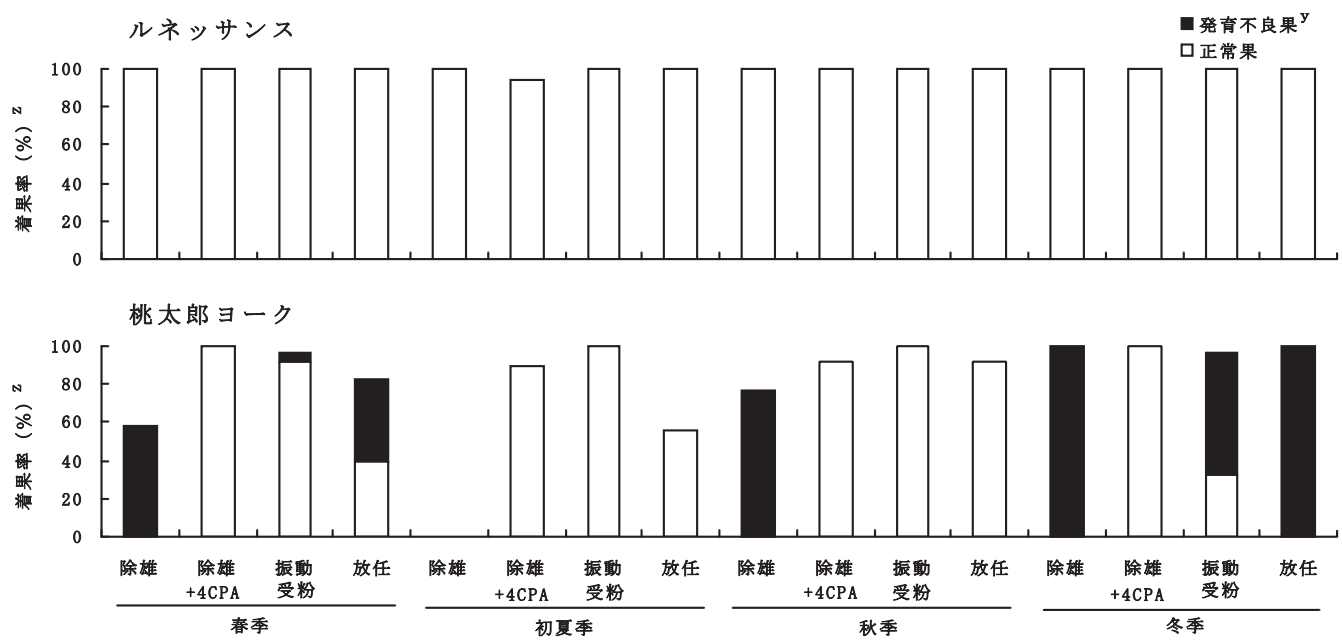

第 1 図時季および花（花蕾）の処理が着果率に及洔す影響 $\mathrm{z}$ 着果数 $/$ 開花数 $\times 100$

$\mathrm{y}$ 着色が通常の果に比べ遅れ，つやがなく，肥大が明らかに悪い果実 


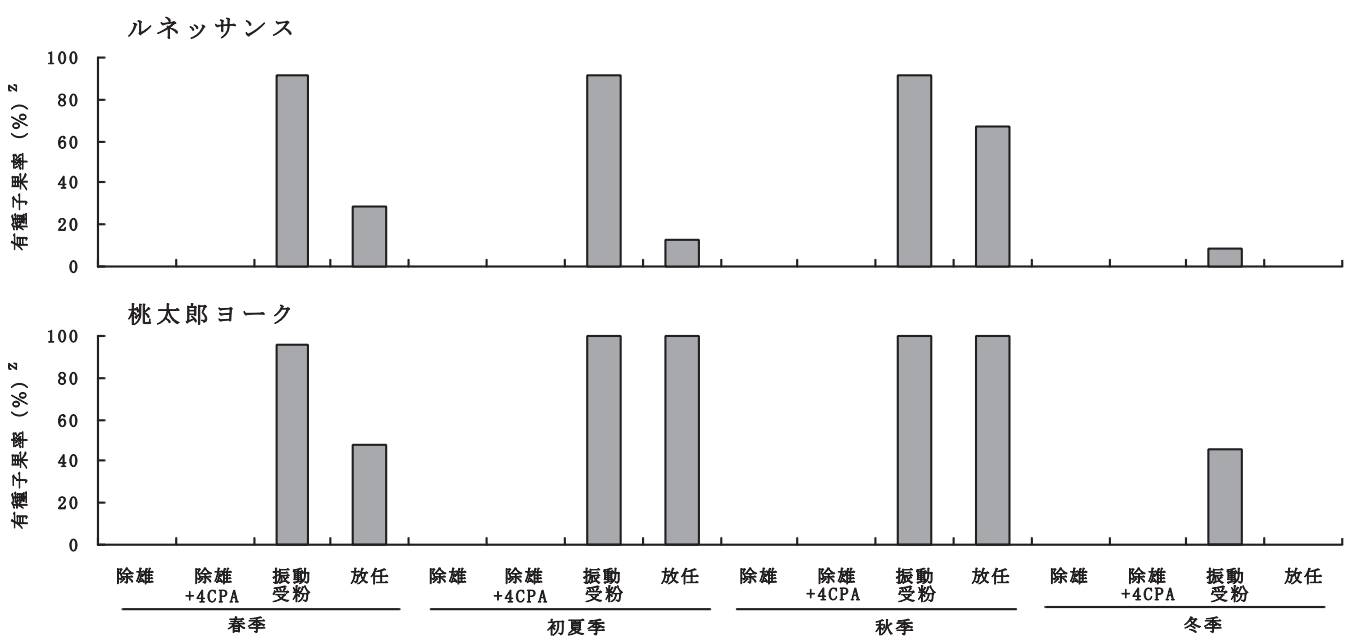

第 2 図時季および花（花蕾）の処理が有種子果率に及ぼす影響 $\mathrm{z}$ 有種子果数 $/$ 着果数 $\times 100$

第 1 表 時季および花（花蕾）の処理が‘ルネッサンス’の果実特性に及添す影響

\begin{tabular}{|c|c|c|c|c|c|c|}
\hline 時季 & 花（花蕾）処理 & 調査果数 & $\begin{array}{l}\text { 開花から収穫 } \\
\text { までの日数（日） }\end{array}$ & 一果重（g） & 種子数（粒／果） & 空洞程度 ${ }^{\mathrm{z}}$ \\
\hline \multirow[t]{4}{*}{ 春 } & 除雄 & 24 & $61.5 \pm 0.5 \mathrm{a}^{\mathrm{y}}$ & $192.8 \pm 9.6 \mathrm{a}$ & $0.0 \pm 0.0 \mathrm{a}$ & $0.1 \mathrm{a}$ \\
\hline & 除雄 +4CPA & 24 & $60.9 \pm 0.6 \mathrm{a}$ & $211.4 \pm 10.0 \mathrm{a}$ & $0.0 \pm 0.0 \mathrm{a}$ & $0.5 \mathrm{~b}$ \\
\hline & 振動受粉 & 24 & $59.7 \pm 0.6 \mathrm{a}$ & $187.5 \pm 7.6 \mathrm{a}$ & $23.9 \pm 5.0 \mathrm{~b}$ & $0.3 \mathrm{ab}$ \\
\hline & 放任 & 24 & $60.6 \pm 0.5 \mathrm{a}$ & $209.3 \pm 8.4 \mathrm{a}$ & $5.9 \pm 3.1 \mathrm{a}$ & $0.5 \mathrm{ab}$ \\
\hline \multirow[t]{4}{*}{ 初夏 } & 除雄 & 14 & $42.4 \pm 0.4 \mathrm{a}$ & $155.5 \pm 8.8 \mathrm{a}$ & $0.0 \pm 0.0 \mathrm{a}$ & $0.1 \mathrm{a}$ \\
\hline & 除雄 +4CPA & 11 & $41.7 \pm 0.4 \mathrm{a}$ & $162.1 \pm 9.6 \mathrm{a}$ & $0.0 \pm 0.0 \mathrm{a}$ & $0.0 \mathrm{a}$ \\
\hline & 振動受粉 & 14 & $42.8 \pm 0.5 \mathrm{a}$ & $162.6 \pm 8.2 \mathrm{a}$ & $49.9 \pm 13.5 \mathrm{~b}$ & $0.0 \mathrm{a}$ \\
\hline & 放任 & 16 & $42.7 \pm 0.3 \mathrm{a}$ & $165.0 \pm 9.5 \mathrm{a}$ & $2.1 \pm 1.7 \mathrm{a}$ & $0.0 \mathrm{a}$ \\
\hline \multirow[t]{4}{*}{ 秋 } & 除雄 & 12 & $73.7 \pm 0.8 \mathrm{a}$ & $172.5 \pm 7.9 \mathrm{a}$ & $0.0 \pm 0.0 \mathrm{a}$ & $0.0 \mathrm{a}$ \\
\hline & 除雄 +4CPA & 12 & $71.2 \pm 0.8 \mathrm{a}$ & $167.2 \pm 9.2 \mathrm{a}$ & $0.0 \pm 0.0 \mathrm{a}$ & $0.0 \mathrm{a}$ \\
\hline & 振動受粉 & 12 & $73.2 \pm 0.4 \mathrm{a}$ & $179.8 \pm 13.4 \mathrm{a}$ & $19.0 \pm 8.1 \mathrm{~b}$ & $0.0 \mathrm{a}$ \\
\hline & 放任 & 12 & $71.7 \pm 1.2 \mathrm{a}$ & $154.8 \pm 6.4 \mathrm{a}$ & $11.4 \pm 5.1 \mathrm{ab}$ & $0.0 \mathrm{a}$ \\
\hline \multirow[t]{4}{*}{ 冬 } & 除雄 & 24 & $83.9 \pm 1.1 \mathrm{a}$ & $208.6 \pm 6.1 \mathrm{a}$ & $0.0 \pm 0.0 \mathrm{a}$ & $0.1 \mathrm{a}$ \\
\hline & 除雄 $+4 \mathrm{CPA}$ & 23 & $83.3 \pm 1.3 \mathrm{a}$ & $190.2 \pm 9.6 \mathrm{a}$ & $0.0 \pm 0.0 \mathrm{a}$ & $0.0 \mathrm{a}$ \\
\hline & 振動受粉 & 24 & $83.5 \pm 0.7 \mathrm{a}$ & $197.5 \pm 10.9 \mathrm{a}$ & $0.2 \pm 0.1 \mathrm{a}$ & $0.0 \mathrm{a}$ \\
\hline & 放任 & 24 & $82.1 \pm 1.0 \mathrm{a}$ & $194.9 \pm 8.7 \mathrm{a}$ & $0.0 \pm 0.0 \mathrm{a}$ & $0.0 \mathrm{a}$ \\
\hline
\end{tabular}

${ }^{\mathrm{z}} 5$ 段階評価 $(0:$ 無, $1:$ 軽, $2:$ 中, $3:$ 重, $4:$ 甚 $)$

同一時季内の異なるアルファベット間には 5\%水準で有意差あり（Steel-Dwass test）

$\mathrm{y}$ 平均值 \pm 標準誤差 $(\mathrm{n}=$ 調査果数)

同一時季内の異なるアルファベット間には $5 \%$ 水準で有意差あり（Tukey-Kramer test）

よび秋季において, 放任区が除雄 +4CPA 区拈よび振動受粉 区に比べて軽かった.

一果当たりの種子数は，両品種ともいずれの時季でも振 動受粉区が放任区に比べて多かった．品種別では，“桃太郎 ヨーク’が‘ルネッサンス’ に比べて多かった。

空洞果は, ‘ルネッサンス’では時季および花 (花蕾) の 処理に関係なく発生は少なかったが，“桃太郎ョーク’では 春季の除雄 $+4 \mathrm{CPA}$ 区が空洞程度 1.4 , 秋季の除雄 $+4 \mathrm{CPA}$ 区 が空洞程度 1.3 と 4CPA の処理区でやや発生した（第 1 表, 第 2 表).

\section{考察}

本研究に括ける非単為結果性品種の ‘桃太郎ョーク’は, 振動受粉の場合に春季，初夏季招よび秋季では着果率は高 く, 大部分は正常果であったが，冬季では着果率は96\%で あったものの, その約 7 割が発育不良果であった。これは, 冬季では施設内の最低温度を $10^{\circ} \mathrm{C}$ で管理したため，雄ず いの花粉稔性が低下し（藤下，1970）, 振動受粉を行っても 受精が不十分となって発育不良果が多発したためと推察さ れる. 放任の場合は, 着果した果実のらち春季で約半数が, 冬季で $100 \%$ が発育不良果であり，初夏季ではすべてが正 
第 2 表 時季および花（花蕾）の処理が‘桃太郎ヨーク’の果実特性に及ぼす影響

\begin{tabular}{|c|c|c|c|c|c|c|}
\hline 時季 & 花（花蕾）処理 & 調査果数 & $\begin{array}{c}\text { 開花から收穫 } \\
\text { までの日数（日） }\end{array}$ & 一果重（g） & 種子数（粒／果） & 空洞程度 ${ }^{\mathrm{Z}}$ \\
\hline \multirow[t]{4}{*}{ 春 } & 除雄 ${ }^{x}$ & - & - & - & - & - \\
\hline & 除雄 $+4 \mathrm{CPA}$ & 23 & $54.0 \pm 0.7 \mathrm{a}^{\mathrm{y}}$ & $237.8 \pm 20.4 \mathrm{~b}$ & $0.0 \pm 0.0 \mathrm{a}$ & $1.4 \mathrm{~b}$ \\
\hline & 振動受粉 & 22 & $56.0 \pm 0.5 \mathrm{ab}$ & $217.1 \pm 13.9 \mathrm{~b}$ & $179.4 \pm 17.0 \mathrm{~b}$ & $0.1 \mathrm{a}$ \\
\hline & 放任 & 9 & $58.0 \pm 1.5 \mathrm{~b}$ & $135.9 \pm 12.6 \mathrm{a}$ & $24.4 \pm 4.1 \mathrm{a}$ & $0.3 \mathrm{a}$ \\
\hline \multirow[t]{4}{*}{ 初夏 } & 除雄 ${ }^{w}$ & - & - & - & - & - \\
\hline & 除雄 +4CPA & 13 & $38.5 \pm 0.6 \mathrm{a}$ & $203.6 \pm 16.4 \mathrm{~b}$ & $0.0 \pm 0.0 \mathrm{a}$ & $0.0 \mathrm{a}$ \\
\hline & 振動受粉 & 15 & $41.1 \pm 0.5 \mathrm{~b}$ & $201.3 \pm 10.4 \mathrm{~b}$ & $159.5 \pm 15.6 \mathrm{~b}$ & $0.0 \mathrm{a}$ \\
\hline & 放任 & 10 & $42.9 \pm 1.2 \mathrm{~b}$ & $120.9 \pm 9.9 \mathrm{a}$ & $31.6 \pm 11.4 \mathrm{a}$ & $0.6 \mathrm{a}$ \\
\hline \multirow[t]{4}{*}{ 秋 } & 除雄 ${ }^{x}$ & - & - & - & - & - \\
\hline & 除雄 $+4 \mathrm{CPA}$ & 10 & $61.5 \pm 1.3 \mathrm{a}$ & $262.1 \pm 19.9 \mathrm{~b}$ & $0.0 \pm 0.0 \mathrm{a}$ & $1.3 \mathrm{~b}$ \\
\hline & 振動受粉 & 12 & $69.4 \pm 1.8 \mathrm{~b}$ & $254.9 \pm 10.4 \mathrm{~b}$ & $245.0 \pm 13.9 \mathrm{c}$ & $0.1 \mathrm{a}$ \\
\hline & 放任 & 11 & $73.9 \pm 2.8 \mathrm{~b}$ & $181.9 \pm 25.2 \mathrm{a}$ & $73.7 \pm 20.9 \mathrm{~b}$ & $0.5 \mathrm{ab}$ \\
\hline \multirow[t]{4}{*}{ 冬 } & 除雄 ${ }^{x}$ & - & - & - & - & - \\
\hline & 除雄 +4CPA & 17 & $81.9 \pm 1.5 \mathrm{a}$ & $164.2 \pm 15.1 \mathrm{a}$ & $0.0 \pm 0.0 \mathrm{a}$ & $0.0 \mathrm{a}$ \\
\hline & 振動受粉 & 8 & $84.2 \pm 2.3 \mathrm{a}$ & $138.1 \pm 16.2 \mathrm{a}$ & $25.4 \pm 11.5 \mathrm{~b}$ & $0.1 \mathrm{a}$ \\
\hline & 放任 ${ }^{\mathrm{x}}$ & - & - & - & - & - \\
\hline
\end{tabular}

${ }^{\mathrm{z}} 5$ 段階評価 $(0:$ 無, $1:$ 軽, $2:$ 中, $3:$ 重, $4:$ 甚 $)$

同一時季内の異なるアルファベット間には $5 \%$ 水準で有意差あり（Steel-Dwass test）

$\mathrm{y}$ 平均值 \pm 標準䛊差 $(\mathrm{n}=$ 調査果数 $)$

同一時季内の異なるアルファベット間には $5 \%$ 水準で有意差あり（Tukey-Kramer test）

$\mathrm{x}$ 着果した果実のすべてが発育不良果のため数值非表示

wすべてが非着果のため数值非表示

常果であったものの着果率は $56 \%$ にとどまった. このよら に強制的に振動受粉を行っていない条件においては, 春 季, 初夏季および冬季では受粉の機会が大幅に減少して受 精に至らないものが多くなったと考えられる，本来，自家 受精植物であるトマトは, 風による花器の振動が起きやす い条件では比較的容易に受粉・受精が行われるが，施設内 のような閉鎖的な空間では，花を人工的に振動して受粉 （振動受粉）させる必要性は高い. 省力的に受粉を行ら手段 として 1991 年 12 月にヨーロッパから初めて導入されたマ ルハナバチは (小出・林, 1993), 現在, 我が国では年間約 7 万群が利用されているが（光畑・和田, 2005), 施設内を トマトの受粉・受精に適した温度に維持することは勿論, マルハナバチの活動に適した温度にも注意しなければなら ない.

一方, 単為結果性品種の ‘ルネッサンス’ は, 春, 初夏, 秋および冬のいずれの時季でも, 花 (花蕾) の処理に関係 なく着果率は 94〜 100\%と高く, 全てが正常果で発育不良 果の発生はなかった。 ロシアの品種 ‘Severianin’ は, 高温 (Lin ら，1982）や低温（Vardy ら，1989）の条件下において, その単為結果性の発現は安定していると報告されている が, ‘Severianin’ の持つ単為結果性遺伝子 pat-2 を導入して 育成された“ルネッサンス’も，本研究で行ったいずれの 時季でも単為結果性の発現は非常に強く, かつ, 安定して いると考えられる. 池田ら（2003）も ‘ルネッサンス’ 高温や低温の条件下に抏いて安定した結実特性を示したこ とを報告している。これらのことから，“ルネッサンス’は “桃太郎ヨーク’ に比べ受精に不良な環境条件下に打いて,
優れた着果性と発育不良果の発生の少なさにより生産性の 大幅な向上が期待される。 また，マルハナバチの導入時に は，その訪花活動を維持し，かつ，花粉稔性の低下を防ぐ ために最低 $12^{\circ} \mathrm{C}$ 以上での温度管理が必須条件になってい るが，“ルネッサンス’の利用によって最低 $10^{\circ} \mathrm{C}$ の温度管 理が可能になり, 冬季の暖房経費の節減も期待できる.

種子の有無と果実肥大性については, Dempsey・Boynton (1965) がトマトの果重と果実内の種子数について正の相関 関係があると報告している，また，果実の成長は種子の生 産するオーキシンによる細胞伸長ではなく, 発達中の種子 によって形成されるシンク能によるとされている（Varga・ Bruinsma, 1976). 本研究でも, ‘桃太郎ョーク’では種子数 の少ない放任区より種子数の多い振動受粉区で一果重が重 かった。一方, ‘ルネッサンス’では種子の有無と発育不良 果の発生括よび果実肥大性に関連が全くなかった. Kataoka ら（2003）は，単為結果性トマトでは偽胚の発育と果実の 肥大に同調性がみられることを報告していることから, ‘ ネッサンス’を使用する場合には非単為結果性トマトとは 異なり, 積極的に振動受粉を行う意味はなく, 偽胚の発育 を一層促進させる条件を明らかにすることが今後重要と考 えられる。

また, 非単為結果性トマトでは着果の確保のために振動 受粉の他に合成ホルモン剂の処理が行われているが, 開花 から収穫までの日数が短くなる熟期促進効果がある反面, 処理濃度によっては空洞果が発生しやすくなることが知ら れている. 本研究でも, “桃太郎ョーク’では4CPA 液の処 理により, いずれの時季でも正常果率は非常に高くなり, 
初夏季および秋季では収穫所要日数が短く，また春季およ び秋季では空洞程度が高くなった。一方，“ルネッサンス’ は 4CPA 液処理の有無が開花から収穫までの日数や一果重 に及ぼす影響はみられず，空洞程度に及ぼす影響も少な かった. 片岡（2004）は ‘Severianin’を供試し, 開花時に ( (4-chloro-2-hydroxymethylphenoxy) acetate, HCPA) $300 \mathrm{mg} / \mathrm{L}$ で花房を浸漬処理した場合, ‘Severianin’でも空洞果が発生 したと報告している.ただし，本研究とは合成オーキシン の種類が異なり, 処理濃度や品種間の比較は行っていない. 本研究で検討した 4CPA の濃度は $15 \mathrm{mg} / \mathrm{L}$ のみであったた め，他の濃度での影響は不明であるが，この濃度に関する 限り, ‘ルネッサンス’ ‘桃太郎ョーク’に比べて人為的に 与えた 4CPA 液の影響を受けにくいと考えられる。また， 'ルネッサンス’は，いずれの時季でも合成ホルモン剂処理 を全く不要にできることから，処理労力の低減にも大きく 寄与できると考えられる.

以上のように，愛知県の主要作型の開花時期に当たる春 季，初夏季，秋季执よび冬季に捛いて，“ルネッサンス’は 振動受粉や合成ホルモン剂処理を行わなくても，着果率が 高く, かつ果実が十分に肥大した。 な技, 本研究は $3 \sim 4$ 段摘心の短期作で, 1 花房当たり 3 花に制限したために, 比 較的栄養条件が良好であったと推測される. 従って, 今後, 長段栽培のような同化養分の競合が厳しい条件や環境ス卜 レス条件に打単為結果性トマトの着果, 果実特性につ いての検討が必要と考えられる.

\section{摘 要}

愛知県の主要作型の開花時期に当たる春季，初夏季，秋 季および冬季に拈いて, 花 (花蕾) の処理が単為結果性卜 マト品種 ‘ルネッサンス’の着果拈よび果実特性に及ぼす 影響について検討した. ‘ルネッサンス’ は, 春, 初夏, 秋 および冬のいずれの時季に扔いても, 着果率は非常に高く, また発育不良果の発生もみられず, 単為結果性の発現は強 く安定していた。 また, ‘ルネッサンス’では, 種子の形成 や 4CPA 液（濃度 $15 \mathrm{mg} / \mathrm{L}$ ) の処理が果実肥大性扣よび開 花から収穫までの日数に及ぼす影響はみられなかった。各 時季に扣ける優れた着果性と安定した果実肥大性から, “ル ネッサンス’ は非単為結果性トマトと比較して生産性の高 い栽培が可能であると考えられた.

\section{引用文献}

Dempsey, W. H. and J. E. Boynton. 1965. Eeffect of seed number on tomato fruit size and maturity. Proc. Amer. Soc. Hort. Sci. 86: 575-581.

藤下典之. 1970. 各種蔬菜に打ける低温, 高温, 暗黒, 除 雄剤などの処理にもとづく花粉退化とその機構に関す 万研究. 大阪府大紀要（農・生）。22: 111-208.

池田二三高・忠内雄次. 1992. わが国へのツチマルハナバ チの導入経過と果菜類のポリネーターとしての実用
性．農及園. 67(11): 1213-1216.

池田英男・濱田未央・菅原眞治・古川 一・佐藤 卓. 2003 . 高温あるいは低温環境下に打ける単為結果性トマト品 種 ‘ルネッサンス’の結実ならびに果実特性. 園学雑. 72 (別 1) : 230 .

Kataoka, K., A. Uemachi and S. Yazawa. 2003. Fruit growth and pseudoembryo development affected by uniconazole, an inhibitor of gibberellin biosynthesis, in pat-2 and auxininduced parthenocarpic tomato fruits. Scientia Horticulturae. 98: 9-16.

片岡圭子. 2004. トマトに打ける単為結果果実の誘導打よ び発達に関する研究. 生長調節物質の関与と偽肧形成. 京都大学学位論文.

Ho, L. C. and D. Hewitt. 1986. Fruit development. p. 201-239. In: J. G. Atherton and J. Rudich (eds.). The tomato crop. Chapman and Hall, London.

小出哲哉・林 悟朗. 1993. 果菜類におけるマルハナバチ (Bombus terrestris) の利用に関する研究（第 1 報） マ ルハナバチの温室内に打ける活動生態とミニトマトの 着果及び果実品質に対する効果. 愛知農総試研報. 25: 165-170.

Lin, S., W. L. George and W. E. Splittstoesser. 1982. Parthenocarpy and the ability to set fruit under high temperature conditions. Tomato Genet. Coop. Rep. 32: 35-36.

光畑雅宏・和田哲夫. 2005. 作物受粉に抢ける在来種マル ハナバチの利用の可能性と課題. 植物防疫. 59(7): 305309.

Philouze, J. and B. Maisonneuve. 1978a. Heredity of the natural ability to set parthenocarpic fruits in the soviet variety Severianin. Tomato Genet. Coop. Rep. 28: 12-13.

Philouze, J. and B. Maisonneuve. 1978b. Breeding tomatoes for their ability to set fruit at low temperatures p. 54-64. In: Breeding Proc. Eucarpia Tomato Working Group (ed.). Genotype and Environment in Glasshouse Tomato. Leningrad, USSR.

斎藤 隆. 1995. キュウリの単為結果に関与する生理生態 的要因. 園学雑. 64 (別 2) : 304 .

菅原眞治・坂森正博・青柳光昭. 1995. 温室トマトへの単 為結果性因子の導入（第 3 報）単為結果性トマト新品 種「ラークナファースト」の育成. 愛知農総試研報. 27: $167-173$.

菅原眞治・榎本真也・大藪哲也・矢部和則・野口博正. 2002. 完熟収穫型単為結果性トマト品種 ‘ルネッサンス’の 育成経過と特性. 愛知農総試研報. 34: 37-42.

Vardy, E., D. Lapushner, A. Genizi and J. Hewitt. 1989. Genetics of parthenocarpy in tomato under low temperature regime: II Cultivar 'Severianin'. Euphytica 41: 9-15.

Varga, A. and J. Bruinsma. 1976. Roles of seeds and auxins in tomato fruit growth. Z. Pflanzenphysiol. 80: 95-104. 